\title{
Problematising Testimony in Autobiographical Narratives by Dalit Women in the English Translation
}

\section{Pratibha}

Ph.D. Research Scholar, Department of English, Jamia Millia Islamia, and Assistant Professor, Sharda University. ORCID id: 0000-0001-5698-6612

Email: pratibhabiswas85@gmail.com, pratibha.biswas@sharda.ac.in.

\begin{abstract}
Dalit autobiographical narratives are widely and habitually being categorised by critics as testimonios or sociobiographies, with an implication to be understood as representative life-stories. Because of the genre's perceived emphasis on 'authenticity', 'representation of collective suffering', and immanent connotations of being a political genre of speech for the marginalised, scholars/critics of Dalit literature have been applying the term testimonio to describe autobiographical narratives, which has inadvertently led to a normativisation of the available modi of 'truth production' about Dalit lived experiences. The objective of this paper is to dispute the adulatory assessment of testimonio as a genre, by highlighting the instances where the relationship between the self and the community in autobiographical narratives by Dalit women appears uneasy, fraught with dissensus and problematic, when examined from a Dalit feminist standpoint. By looking into ways of reading agency in Karukku (2000), Sangati (2005), and Viramma, Life of an Untouchable (1997), beyond the true-false, victim-oppressor and Dalit-Savarna simplistic binaries, this paper enunciates the problematic implications of using the nomenclature testimonio for reading these autobiographical narratives translated in English. Further, it posits arguments for shifting the emphasis on the politics of language and narrative to avert the trappings of the genre.
\end{abstract}

Keywords: Dalit autobiographical narratives, testimonio, self and the community, Dalit feminism, literature and politics, Dalit literature in translation, translation and agency.

\section{Introduction}

Sharan Kumar Limbale (2004) in Towards an Aesthetic of Dalit Literature insisted on separate criteria for artistic standards and aesthetic yardsticks for critical evaluation of Dalit literature. He describes Dalit literature as "a lofty image of grief," the kind that portrays sorrows, tribulations, slavery, degradation, ridicule and poverty $(2004$, p. 31). Further, he argues that as this literature is a product of Dalit consciousness and is shaped by the authentic lived experience of suffering, it becomes impossible for non-Dalits to articulate this sensibility faithfully. This view was also espoused by Omprakash Valmiki, who stressed the importance of "the truth as one has experienced it, depicting just as it was seen and felt" (cited in Brueck, 2010, p. 353). Laura R Brueck 
(2010) interprets this as a conscious and calculated initiative to establish and guard public space for Dalit literature carefully to enable it to emerge, a "rhetorical strategy to control their own representation in literary mainstream" (p. 348). Brueck even remarks that "once established, [Dalits] may allow the boundaries of that space to be opened to embrace much more diverse understanding to Dalit experience" (2010, p. 357).

Perhaps, it is a consequence of the earlier insistence on authenticity and lived truth, that Dalit autobiographical narratives are frequently posited as testimonios, communicating veritable descriptions of the life of dehumanisation, discrimination, exploitation and starvation. George Yudice (1991) defined testimonial literature as:

an authentic narrative, told by a witness who is moved to narrate by the urgency of a situation (war, oppression, revolution, etc.). Emphasising popular, oral discourse the witness portrays his or her own experience as an agent (rather than a representative) of a collective memory and identity. Truth is summoned in the cause of denouncing a present situation of exploitation and oppression or in exorcising and setting aright official history. (p. 17)

Initially emerging from the Latin American narratives of exploitation by indigenous communities, the term testimonio in the Dalit context was emphasised by Sharmila Rege (2013) to speak of collective pain and suffering, so as to articulate the emancipatory potential of Dalit feminism in political and pedagogical fields. In the Introduction to her book, Writing Caste/ Writing Gender, Rege enunciates (citing Gopal Guru) the subversive potential of these historical narratives called 'testimonies' for "resurrecting dalit triumphalism" and "recording social wrongs done by the ancestors" (2013, p. 19). Following Lokhande, who pointed out that brahmanical patriarchal practices within the community were inadequately remembered in Dalit men's testimonies (where women were selectively remembered primarily as wives and mothers or victims of caste-based practices, further essentially relegating the role of supporters in a larger cause), Rege proposes that Dalit women's testimonies as alternative accounts, offer:

public articulation of relational identities of caste and gender, thus inscribing into history not only what dominant groups would like to forget... but also the selective memory of the community. (2013, p. 99)

Rege's definition is drawn from John Beverly's (1991) definition of testimonio, as a narrative told in the first person by a narrator, who recounts a significant life experience as the protagonist and witness, therefore claims some agency in the act of narrating, inciting the reader to respond by actively judging the situation. Rege also refers to Pandian's comment on Bama's Karukku, that by depleting the autonomous "I" - symptomatic of bourgeois individualism, and replacing it with the collectivity of the Dalit community, testimonios "create new generic possibilities and invite different ways of being read" (2013, p. 17). According to her, because the self seeks affirmation in a collective mode, these narratives can also reveal the dialectic of the self and the community, by challenging the singular communitarian notion of the Dalit community.

Rege's arguments are sound. The socio-political and historical significance of testimonials in gaining material and symbolic redress and in fostering grassroots activism cannot be denied. Yet, the nomenclature in the literary context is highly problematic, as it tends to negate the text's 
mediatedness or literariness. As pointed out by Laura R. Brueck (2014) in Writing Resistance: The Rhetorical Imagination of Hindi Dalit Literature, treated as 'repositories of 'subaltern truths', the interpretation of these narratives is mostly linked to developmental needs with sociological and activist import, leading to glossing over of the stylistic aesthetics and formalistic analysis. Brueck argues that "there has been scant attention paid to the ways in which Dalit writers consciously stylise their narrative form to construct social and political meaning" (2014, p. 6). Thus, treating these texts as unmediated documents of singularly "authentic" experience, is problematic.

\section{Problematising testimony}

Rege quotes Beverly's definition in a truncated manner, obfuscating the part where he states that, " $[t]$ he position of the reader of testimonio is akin to that of a jury member in a courtroom. Unlike the novel, testimonio promises by definition to be primarily concerned with sincerity rather than literariness" (2004, p. 65). Sandra Henderson, in "Latin American Testimonio: Uncovering the Subaltern's Gender Race and Class," observes that it is vital to be mindful of what definitions emphasise and what they leave out. Henderson highlights that Beverly's courtroom analogy with the reader as a juror, creates a hierarchy of approval over women's perception of their own lives, as the reader gets placed in an authoritative position to decide whether or not the testimony is true (2001, p. 2). This idea is also resonant in the objection voiced by Gopal Guru in the Afterword to the book, The Prisons We Broke. According to him, testimonio as the substitute term for Dalit personal narratives, is problematic on two grounds. First, as a mode of representation embedded in legal discourse, it puts the responsibility to provide evidence for proving innocence on the narrator as a casualty, relegating him/her to a pleading mode. Second, such a stance repudiates the possibility to interrogate the judge, by elevating him/her to a privileged position (Guru in Kamble, 2008, p. 159). However, he defends the use of the term "as a powerful moral medium to protest against the adversaries, both from within and outside" the category, by involving "the conception of the narrative self" (Guru in Kamble, 2008, p. 160).

Additionally, testimony, in a legal sense, also makes verifiable identity a precondition. In cases where competing truth claims are presented, their judgment may require further personal revelations, sometimes against the will of the witness. A failure to tell the truth also implicates the voice of the witness in crime and punishment. Moreover, Anupama Rao (2003), in her analysis of the Sirsagaon atrocity, examines the nexus among law, violence and Dalit identity, to illustrate the troubled form of visibility rooted in vulnerability, that the law engenders for Dalit women. She explains the law's violence of recognition, which requires an act of gendered violation to be turned into a case, to mobilise bureaucratic structures of redress. As Rao states:

Legislation only remembers its own language of verification. Case law and precedent play the role of juridical memory, in that they define the parameters of possible arguments, and the possibilities for establishing motive, intention and "good" evidence. The selective use of the accused and victim's life worlds then becomes read through the language of necessity: what is the bare minimum of external facts that may be drawn upon to make an event/incident into a case with its own rigours of analysis and interpretation. (2003, p. 296)

Considering these arguments as frameworks to examine the primary texts, in my observation, in a feudal, patriarchal caste set-up where caste and gender ideology collude to silence Dalit women, 
in most cases of harassment, these women are most often denied even the possibility to claim the position of a victim. For instance, Mariamma's account recalled by Bama in Sangati is illustrative here. Mariamma is molested by Kumarasami Ayya in his fields near the pump-shed while returning home after collecting firewood. She somehow manages to escape from the evil landlord's clutches, yet she is advised to keep quiet when she confides her ordeal to her friends. According to them, if the matter becomes public, it would be she who would get blamed. While Mariamma is silenced, Kumarasami Ayya, afraid of getting his reputation tarnished, is the first to approach the Paraiya community's headmen to complain about Mariamma's misdemeanour. He concocts a false account of having caught Manikkam and Mariamma in a compromising position in his pump shed. Influenced by his story, more so by his power and status, the village elders call a meeting in the community hall. This meeting is attended chiefly by menfolk and a few women who stand on the fringe. The elders initially do not even consider questioning the boy and the girl to defend or justify themselves. When Karuppayya insists that the youngsters must be questioned, Malayaandi angrily retorts:

Question them? Why should we question them? Didn't the mudalaali see them with his own eyes and then come and complain? We have to decide what their punishment should be, that's all. (Bama, 2005, p. 22)

However, eventually better sense prevails, and the girl and the boy are given a chance to give their testimony. Both instate that they met briefly while collecting firewood, exchanged small talk because they were relatives, but then they had returned separately. They had not met each other on the way. Manikkam speaks humbly, standing with his arms folded in supplication. Mariamma, who had felt terribly traumatised by it all, barely manages to stop herself from crying, before she finishes what she has to say to corroborate Manikkam's account. The elders give more credibility to the landlord's account, and discredit the testimony of the youngsters, to render them accused instead of victims. At this moment, one among the women watching the trial, Kaliamma tries to intervene. She attempts to register her testimony as a witness, to authenticate the claims of the boy and the girl. Yet, perhaps afraid of reprimand, she speaks as if she is speaking to herself:

That akka Mariamma went away with her firewood a long time before all the rest of us. Machaan Manikkam helped to lift my bundle on to my head, and then walked home behind me. How could these two possibly have met and misbehaved? This is really unjust. Look at the cheek of the mudalaali. He came here as fast as he could and told his fibs. (Bama, 2005, p. 23)

But, she is also muted, and her account is violently dismissed by a few men, who get up and start shouting abuses at the women for daring to speak. As Bama writes: "Once again the women were silenced" (2005, p. 23). Consequently, the junior naattaamai calls Mariamma's father Samudrakani to give away the verdict, according to which Mariamma is asked to "fall down and beg for forgiveness" and pay a monetary fine to close the matter. Infuriated by the humiliation, in response, Samudrakani admonishes Mariamma and asks her to comply by begging for forgiveness (Bama, 2005, p. 23). Overwhelmed by it all, perhaps more by the unjustness of the punishment, the girl, unable to contain herself anymore, begins to cry loudly and blurts out the truth about her molestation by the landlord. Ironically, this only provokes the elders further, who accuse her of conniving to blame the landlord for escaping mortification. Not only is she proven guilty, shamed 
publicly and called a slut, but she is also made to pay a fine of Rs 200. Manikkam, contrarily, is fined Rs 100. Aspersions are also cast on Mariamma's character, partly because her father already had a reputation for keeping mistresses. So, it is deduced by another woman Muthamma, that Mariamma could be promiscuous. However, another woman responds that the entire village was aware of Mariamma's father's philandering habits, but never had a village meeting been summoned to question him. In her words: "They say he's a man. . . . It's one justice for men and quite another for women" (Bama, 2005, p. 24).

This episode illustrates the issues of procedural fairness, gender biases and the possible threat to security, immanent in public hearings for Dalit women. It shatters the myth that public hearings are an inherently democratic medium of truth production, as speaking out in public may not be a relieving experience for the survivor. In most cases, victims suffer censorship, slander and repression - not just by the oppressor but also by their own community. The testimonial speech act, then, has dual potential as a way of gaining material or symbolic redress. It may yield justice, or on the contrary, prove risky, leading to further humiliation, and in extreme cases, rape, torture or atrocity. The description of Mariamma's humiliation comprises a significant section of Chapter 2. With much attention here, Bama deftly makes a two-pronged representation. On one hand, she exposes the patriarchal tendencies working in collusion with casteist power structures, that are inimical to the emergence of Dalit women's testimony from within the community. On the other, she uses her narrative voice as a medium to allow the silenced testimonies of women of her community to unfold in the readers' minds. Based on this instance where testimony emerges as a distinct trope, and considering the general structure of Sangati, calling it a testimonial narrative seems befitting, but this term does not hold as good for the other primary texts under study.

In the critique available on the interpretation of Dalit literary texts as resistance literature, there has been, evidently, a tendency to apply the term testimonio uncritically. Because of the genre's perceived emphasis on 'authenticity' and 'representation of collective suffering', scholars/critics of Dalit literature have been urging the readers to read autobiographical narratives as testimonies, which has led to a fixation of the available modi of truth production. This is evident in S. Shankar's (2012) comments about Viramma's narrative in "Pariah, or the Human or the Vernacular" and Sara Sindhu Thomas's (2016) in "Witnessing and Experiencing Dalitness: in Defence of Dalit women's Testimonios". Even, M.S.S. Pandian in his essay "On a Dalit Woman's Testimonio," calls Karukku "perhaps the first dalit testimonial narrative in Tamil" (2003, p. 131). Contradictorily, Pandian acknowledges and cites Mark S. J. at the end of the same paragraph, who states in the Foreword of the text that, "[a]t the first sight it reads like a history of a village. From another angle, it reads like an autobiography. From yet another angle, it reads like a brilliant novel. .. Bama's is a case of willfully violating genre boundaries" (2003, p. 131). Despite identifying the genre-defying quality of the narrative, Pandian boxes his analysis into the category of a testimonio. Contrarily, at an international conference on "Dalit Literature and/in Translation" held at the University of East Anglia, U.K., in 2015, Bama describes the text as a 'social autobiographical novel' and not a testimonio.

According to Franka Winter (2009), based on subjective and personal truth, while testimony in subaltern studies is interpreted as a political genre of speech by people who are marginalised, repressed and exploited, yet if not accompanied by the opening of other influential 
genres of speech to subaltern people, "genres of speech explicitly reserved and established for subaltern voices only serve as a fig-leaf. They foster resubalternization and rather add to stabilising and legitimising, than to overcoming, inequality" (p. 104). In my observation, a thrust on claims of being a non-mediated expression, also obfuscates the contribution or intervention made by the social researchers, the editors, the translators as 'coaxers/coercers' in facilitating the production, publication and incorporation of these narratives in academic discourse and the literary realm. The argument is based on the tripartite schema suggested by sociologist Ken Plummer (1995), who purports that every story action is made by three kinds of contributors: (1) the teller of the story (the autobiographical narrator), (2) the coaxer/coercer who solicits or provokes the production of the story (persons or institutions or set of cultural imperatives), and (3) the consumers who interpret the story (readers and audience) (pp. 20-21).

Disputing the empiricist conception of testimonies, to argue in favour of dialogical hermeneutic research, Jorge Ivan Vergara (2018) opines that the popular metaphor "voice of the voiceless," disguises the dialogue between the researcher and the individual. Highlighting the importance of the interview method as a standard/habitual method, though not the only modality of producing a testimonio, he decries the assumption that testimonies are a 'spontaneous reflection' (2018, p. 268). During the interview, a mutual adjustment of interest and expectations occurs between the interviewer and the interviewee. The narration is often framed and conditioned by the interviewer's questions and gestures, influencing the interviewee's response (Vergara, 2018, pp. 269-270). To support his observation, Vergara (2018) cites Kirai de León (1986) who says:

we can define the process of narration as a performance, where the observer-recorder represents the less active role - even though he stimulates and sets the course for the narrator and is the receiver of the result of the interaction. (pp. 269-270)

The aspect of mutual adjustment of expectations and the researcher's role as a coaxer and as the framer of the narrative, are overtly made evident in the Translator's note attached to Viramma: Life of an Untouchable. During her ethnomusicological research, Josiane Racine had taken Viramma as a respondent for her knowledge of popular songs and laments. It had taken five years of conversation and friendship between the two women, coming from very different classes and castes, to establish the sense of trust for Viramma to be able to speak more openly about her hardships, provocative feelings and criticism of the established order; things that she had glossed over earlier. "What had only been commented on in passing would be described more fully when it was brought up again later, or when a tape of a previous conversation was played back to her..." (1997, p. v). This clearly indicates the shaping influence exerted by Racine over Viramma's account. The mediated nature of Viramma's narrative, is also substantiated by the revelation made in the Translator's note, that states the text which came to be published as a narrative in 1995 in French (translated from Tamil), was selected by Josiane Racine from the taped material (conversations with Viramma) collected over ten years. 
What complicates the veracity of the authenticity claim further in autobiographical narratives taken as testimonios, is that in some cases, the interviewee may also hide certain aspects of her or the group's life. For instance, Rigoberta Menchu states':

of course in all my narration I believe I project an image of people, but still keep hiding my Indian identity. I keep hiding what I feel nobody knows, not even an anthropologist or an intellectual, no matter how many books they have, they cannot distinguish all of all secrets. (cited in Vergara, p. 271)

Vergara argues that the intention here is not to denounce the testimonial account's truthfulness, but rather to acknowledge the diversity or the degree of the narrator's subjectivity, in discursively constructing and interpreting her experience in a profoundly unequal social communication. Anuradha Dingwaney and Carol Maier (1995) have illustrated that the effect of transparency of Menchu speaking directly to readers, could have been a calculated strategy to elicit sympathy, compassion and a sense of morality/justice from the readers, since the narration got multiply mediated first in the Spanish edition and especially in its English translation. To compel the reader to identify with the narrator, and to preserve the full urgency of political activism - a testimony must seem to be unmediated. It should have transparency that visibilises the brutalities and repressions, one witnesses. According to Dingwaney and Maier, in such a scenario, the specific challenge faced by the translator then is:

to enable a reader to identify with her cause, her political agenda, without assuming her identity, even though to identify with her cause may entail imagining oneself in her place. (1995, p. 309)

The ethnographer Burgos-Debray had omitted her questions, that otherwise would have organised the material. Instead of reading this as an attempt to suppress or evade truth, one can read it as a tactical move. The English translation from Spanish by Ann Wright, likewise, simulated the effect of transparency, creditably performing the task of the translator to initiate readers into this category of human rights literature.

Burgos-Debray solicited Menchu's life story, while they both happened to be in Paris. The fact that Menchu recounted her narrative in Spanish, which she claimed to have only recently learned, is considered a transgressive move by Dingwaney and Maier, because she learned Spanish despite her father forbidding her to do so. In Menchu's words:

They have always said, poor Indians they can't speak, so many speak for them. That's why I decided to learn Spanish. (Burgos-Debray, 1984, p. 157)

Dingwaney and Maier read this as symptomatic of Menchu's complex agency in co-creating her account, which garnered international concern for the indigenous Guatemalan Indians, whom she represents. Thus, we see how it is the 'effect of authenticity', that lends a political edge to testimonies than the truth itself. It implies that as far as the 'effect of authenticity' can be recreated

\footnotetext{
${ }^{1}$ Rigoberta Menchu, an activist from Guatemala who won the Nobel Peace Prize in 1992, wrote an autobiography (I, Rigoberta Menchu: An Indian Woman in Guatemala) that was later shown to contain inaccuracies. An anthropologist, David Stoll, asserts that Rigoberta Menchu writes about experiences she never had herself.
} 
in literary representation, other genres can also be made amenable to politics. To achieve this, rather than displacing the concerns to what is outside literature, such as 'truth', it must be acknowledged that the politics of literature unfolds at the level of language, in the shaping of the literary content, and in translation which is a multiply mediated site and has contingent ramifications - linguistic, cultural, ideological and even political.

Before the issue of language and politics in Dalit literature is taken up in greater detail, it is pertinent to address here, the leveraging role of translation that recreates the effect of authenticity by rendering 'invisible' the mediations by the translator. Dalit writers are increasingly endorsing and encouraging translations of their narratives originally rendered in vernacular as they know and have acknowledged the amplifying effect of translation on disseminating Dalit experience. Translation re-encodes Dalit experience for non-Dalit readers. For instance, in 2015, Bama, as one of the participating delegates at an international conference on "Dalit Literature and/in Translation" held at the University of East Anglia, U.K., shared the experience of her work Karukku being translated into English. After publication, the narrative had received tremendous appreciation as well as criticism for her work. At that early juncture, when it was being critiqued for its style, content and form, Bama had received Mini Krishnan's offer (then editor of Macmillan Books) of translating it into English. In Bama's words:

I accepted the offer and I was lucky that Ms. Lakshmi Holmstrom was to be my translator. We met together with Mini Krishnan a few times, discussed and clarified many things through correspondence. I was very pleased with the translation because she was able to preserve to a great extent the oral nature of the text with its everyday dialectical, colloquial style and earthy and people's language and the dynamism of the characters without compromising in any way the impact of the storyline or whittling the issue of dalit rights. The translation got the Crossword award and it has been prescribed in the syllabus by many Universities and more than 100 M.Phil. and a few doctoral theses have been written on it. The translation did help to bring to the public gaze and conscience the denial of our right to be human and. . . become a part of global discourse on human rights. Translation has also changed my life and it took me to international conferences for literary exchanges and human rights issues. ... I also believe that the translation has an identity of its own. Isn't it a merging of horizons of the author and translator, of the context then and the context now where the cultural specificities find their universal meanings? Probably, translation is not only a language event but the most humanising moment. ("Abstract," 2015, p. 2)

Bama's words substantiate her efforts in 'co-creating her agency' in the translated text and the mediated 'effect of transparency' in the translated text. Bama commends the translator for retaining the 'effect of authenticity' in her narrative. She also emphasises the fortifying influence of the translator in facilitating greater visibility to her narrative internationally. Nalini Pai has also pointed this out in her essay, "Language and Translation in Dalit Literature," that in the case of Sangati as well, Bama admits to having exercised her intervention in translation, "having worked with the translator and on account of her knowing English" (2018, p. 87). Thereby, this indicates Bama's agency in co-creating the translated text with Holmstrom. Pai also reads this instance of collaboration as Holmstrom's getting intimate with the text, by referring to her comment in the 
Introduction of the second edition of Karukku, where Holmstrom as the translator uses Spivak's phrase and admits the need to 'surrender to the special call of the text'2 $(2018$, p. 87).

Now, let me address the issue of locating politics in Dalit literature. In "The Politics of Dalit Literature," Ravi Shankar Kumar (2018) maps the existing approaches to the relationship between literature and politics, to state that the dominant perspective in Dalit literary criticism is deterministic, as literature is more or less treated as a mere supplement to the Dalit movement. For instance, Sharankumar Limbale defines raising the consciousness of the Dalit masses as the aim of Dalit literature. Similarly, Om Prakash Valmiki held the view that literature serves to create the ideological background for political movements. Countering this perspective, Kumar argues that Dalit literature must be perceived as more than just a catalyst for Dalit politics. He borrows the ideas of Jacques Ranciére to suggest that at the level of the text and interpretations, the politics of literature is posited in the sense that it reconstitutes the 'sensible realm'. As Ranciére proposes:

The politics of literature is not the same thing as the politics of writers. It does not concern the personal engagements of writers in the social or political struggles of their times. Neither does it concern the way writers represent social structures, political movements or various identities in their books. (cited in Kumar, 2018, p. 41)

Kumar proposes that this approach would enable the politics performed by the social life of the text (through successive readings and interpretations), to be separated from the politics of the authors. In Kumar's words:

A literary text is a realm of production, reproduction and representation as well as distortion of reality and meaning. From this perspective, a text achieves relative autonomy from the superimposition of assumed social reality. Such a perspective allows us to reflect upon the constitutive and performative role of the text in the production of meanings. A literary text in this sense overcomes the supplementary role of mere reflection and representation of the social world and reality. This does not mean literature gets cut off from the 'world of life'. Rather, it suggests that the 'world of letters' and the 'world of life' are both ways of experiencing and articulating life. (2018, p. 43)

Kumar further argues that it is in the 'language of caste', where Dalit literature's politics has to be located. This claim is based on M.S.S Pandian's enunciation, that in postcolonial India, there are two possible ways to read/write the language of caste, namely: (i) caste in the language of caste itself and (ii) caste by other means, whereby it is delegitimised from the public sphere and masquerades as something else. Kumar then emphasises that it is through literature as a representational realm, that the language of caste is being reconstituted, by a transformation of caste as an experiential category to caste as a political category:

In giving an account of oneself, Dalit writers simultaneously give an account of the unaccounted and the unaccountable events, people and persons that are often seen as being not worthy of an account. (2018, p. 53)

\footnotetext{
${ }^{2}$ In her essay 'The Politics of Translation' (1993) Gayatri Chakravarti Spivak mentions: 'translation is the most intimate act of reading. I surrender to the text when I translate' (180).
} 
The political dimension of these texts is in their capability of "opening new fields of social visibility," whereby what had been hitherto invisible is rendered visible (Kumar, 2018, p. 53). It is pertinent to recall here that Ranciére is cited to enunciate the idea of politics:

Politics is first of all a way of framing, among sensory data, a specific form of experience. It is a partition of sensible, of the visible and the sayable, which allows (or does not allow) some specific data to appear; which allows or does not allow some specific subject to designate them and speak about them. It is a specific intertwining of ways of being, ways of doing and ways of speaking. The politics of literature thus means that literature as literature is involved in this partition of the visible and the sayable. $(2004$, p.10)

The following two instances show a fruitful application of these arguments. First, the polemical nature of Bama's use of the demotic, colloquial and informal Tamil, that overturns the received notions of aesthetics and decorum to visibilise the Dalit world of experience, has been well noted by Holmstrom as well as several other critics. Nevertheless, what Holmstrom notes for Karukku, in particular, is that in rendering the work-chants, folk-songs, songs sung at rites of passage and proverbs used in everyday interaction, the text reclaims space for social visibility of the oral tradition, most of which belongs particularly to Dalit women's domain or involves concerns about family, work and community. Sangati, in particular, is littered with proverbs, impromptu songs, chants, folklore and even jokes and banter, to recreate Dalit women's cultural universe that usually gets glossed over in autobiographical narratives by Dalit men. The very first sentence of Chapter One is: "If the third is a girl to behold, your courtyard will fill with gold" (Bama, 2005, p. 3), registering through the character of the grandmother, the deep-rooted belief in the community about the pattern of birth of babies with respect to their gender, having a significant impact on the fortune of the household.

Other than visibilising the oral culture, the language of violence/abuse, which is usually labelled as non-literary and obscene, is used in autobiographical narratives by women to render domestic quarrels, intra-community brawls within the neighbourhood and inter-community clashes, where they become targets of humiliation and assault. It reflects the dimensions of violence that these women endure on an everyday basis. In my observation, this is true for the other texts under study as well as they render visible the exploitative sexual division of labour, issue of wage disparity, devaluation of labour, household economic exploitation of Dalit women perpetrated within the community. These texts also register the subversive use of the Dalit woman's body as a site of intersection between the private and the public, the personal and the political, where the conception of subjectivity may be rooted, to represent new facets of Dalit women's emboldened selves, unbridled by the rhetoric of victimisation, suffering or exploitation.

Here, another example of how the text reconstitutes the realm of the partition between the sayable and the unsayable, by polemically questioning the authority of Savarna aesthetics in policing the realm of representation, can be cited from The Weave of My Life (2008) by Urmila Pawar. Pawar notes that she had befriended Vilas Kelaskar during the Konkan Marathi Sahitya Sammelana in Sahitya Sangha in Mumbai. Kelaskar, Pawar and another friend of hers (who had lived abroad for some time), would then meet often to discuss the stories they had been writing. During one such meeting, Pawar had felt deeply hurt by the praise Kelaskar had showered on her friend's story, calling it "so civilised, so cultured and so rooted" and without a trace of the other 
language (2008, p. 232). What had then pricked her, was the use of the word, 'cultured'. Pawar writes:

What exactly did he mean? Which culture were they talking about? Whose dominance were they praising? Patriarchy? Caste system? Class? What was it? And why was our writing termed uncivilised, uncultured? How? These questions raged in my mind. (2008, pp. 232233)

Even Viramma, an illiterate woman, articulates clearly the understanding of language being a strong indicator of one's identity. Even though her thoughts lack the radical impulse of Dalit consciousness, in Viramma's words:

... we speak half-language. . . . [it] betrays us every time we open our mouths, even when we are well dressed, even in the market when every-body's mixed together. We are recognised everywhere, at the temple, in the cinema. (1997, p. 194)

By focusing on language as a site of politics rather than the genre, a significant advantage that would accrue to what constitutes the corpus of Dalit Literature is that it would become accommodative of highly subversive articulations and modes of expression, based on humour and ribaldry (such as satire), other than those evocative of pain and humiliation. For instance, in chapter 16 titled High and Low castes in Karani, Viramma speaks of indulging in humour and ribaldry with Naicker. Consider the following highly subversive excerpt from Viramma's narrative that cannot be contained within the oppressor-oppressed framework:

After our husbands, the Reddiar are the people we respect and fear the most. We are their serfs. It's different with other landowners, we sing as much as we want and anyway, they like it. Sometimes when we work for the Naicker, we joke with him. We can even make fun of him. We shout, 'Yennayya! You never stop giving your wife children! She's pregnant every year like a bitch and you'll lose your strength, you won't have anything left, even if you eat melted butter and curds. Come over here a bit, ayya, come and see if your strength is a match for us beef eaters when it comes to real work like this! It makes him laugh to hear us going on like this! That's how we joke with him, Sinnamma, and with other landowners for whom we are not serfs. (1997, p. 157)

\section{Conclusion}

The paper calls to attention the problematic implications of boxing Dalit autobiographical narratives into the category of testimonio, and treating them as unmediated documents of singularly "authentic" experience. Firstly, because the term is taken from the legal register of public hearings, it implies the narrator's expressions to be taken as truth claims. It inordinately creates a hierarchy in the intersubjective space, by positioning the reader as the juror and the narrator as a casualty. The truthfulness of women's perception, then, becomes subject to the authority and approval of the reader. In situations where competing truth claims exist, a failure to tell the truth also implicates the voice of the witness in crime and punishment. Judgement may then require further personal revelations, sometimes against the will of the witness and at odds with his/her best interest. This is exemplified with reference to Mariamma's molestation as recalled by Bama 
in Sangati. The instance illustrates that in a feudal, patriarchal caste set-up, where aggrieved women are most often denied even the possibility to claim the position of a victim, claiming voice as a witness, instead of proving a way of gaining material or symbolic redress, may make the witness dangerously vulnerable to humiliation or other modes of repression such as rape, torture or atrocity. In most cases, as with Mariamma, victims suffer censorship, slander and repression not just by the oppressor, but also by members of their own community, who resort to such measures in an attempt to uphold their honour. Such issues in procedural fairness due to gender biases, shatter the myth that public hearings or testimonies comprise an inherently democratic medium of truth production.

Further, in the literary realm, limiting the mode of representation to testimony, because of its perceived connotations of being a political genre of speech for the marginalised, repressed and exploited, might only lead to their re-subalternization by fostering inequality. The assumption that a testimony is a 'spontaneous reflection', also obfuscates the crucial contribution or intervention, made by the social researchers, the editors, the translators as 'coaxers/coercers' in facilitating the production, publication and incorporation of these narratives in academic discourse. Through relevant examples from the primary texts, it is substantiated that the narration, especially when interview as a method is used to solicit the narration, is often framed and conditioned by the interviewer's questions or gestures, which significantly influences the interviewee's response. These questions are typically omitted in the final published text. There is also a mutual adjustment of interests and expectations between the two. It must also be noted that the translators or editors, mediate the text according to the publishing market's demands, shaping the material to create an 'effect of transparency', a calculated strategy meant to usher the reader into a particular interpretive framework. This effect of the narrator speaking directly to the reader, is created to elicit sympathy, compassion, a sense of morality/justice and urgency towards political activism. It has been explained with reference to Viramma's narrative in this paper. Instead of dismissing it as manipulation to suppress or evade truth, one can read it as a tactical move of 'co-creation of agency', because it compels the reader to identify with the narrator. It creates an intersubjective space for the narrator to be heard and understood by the reader. This argument has been corroborated with reference to Karukku and Sangati, and Bama's intervention in working with Lakshmi Holmstrom in creating the translated versions.

Correspondingly, the term testimonio is also problematic for relegating literature to a supplementary role, as a catalyst for political activism. It deflects attention from the literariness of the text onto the truth claims. To avoid such trappings, a better approach for locating political agency in Dalit literature, would be to situate it in the use of language, through which in literature, caste, that had been hitherto invisible, is rendered socially visible. It is being reconfigured from an experiential category to a political category, through a reconstitution of the partition realm between the sayable and the unsayable. For example, the language of violence/abuse, which is usually labelled as non-literary and obscene, is used in these autobiographical narratives by women to expose domestic quarrels, intra-community brawls and inter-community clashes, where they become targets of humiliation and assault. By focusing on the language as a site of politics instead of the genre, the Dalit literary space can be opened up to other divergent and highly subversive articulations and modes of expression based on humour and ribaldry (such as satire). Not mandating the writer to prove his/her wretchedness as a Dalit, by highlighting mainly the 
experiences evocative of pain and humiliation, would also add greater breadth and diversity of autobiographical experiences to this body of literature.

\section{Funding Disclosure/Acknowledgement}

This research paper did not receive any institutional funding. It has been culled from a section of the author's doctoral dissertation titled Self and Community in Autobiographical Narratives by Dalit Women in the English Translation, submitted at the Department of English, Faculty of Humanities and Languages, Jamia Millia Islamia.

\section{References}

Bama, F. (2000). Karukku (L. Holmstrom, Trans.) Macmillan India Limited. (Original work published 1992)

---. (2005). Sangati (L. Holmstrom, Trans.) Oxford University Press. (Original work published 1994)

---. (2015). Abstract of "Dalit Literature in Translation." Proceedings of Dalit Literature and/in Translation: An International Conference at the British Centre for Literary Translation. University of East Anglia. https://studylib.net/doc/6852386/dalit-literature-and---in-translation

Beverley, J. (1991). The margin at the Center: On 'Testimonio' (Testimonial Narrative). In S. Smith \& J. Watson (Eds.), De/Colonizing the Subject: The Politics of Gender in Women's Autobiography (pp. 91-114). University of Minnesota Press.

---. (2004). Testimonio: On the politics of truth. University of Minnesota Press.

Brueck, L. R. (2010). The Emerging Complexity of Dalit Consciousness. Himal Southasian, 23(1), 44-47. https://www.himalmag.com/dalit-consciousness-literature/

---. (2011). Marking the Boundaries of a New Literary Identity: The Assertion of 'Dalit Consciousness' in Dalit Literary Criticism. In S. E. Lindquist (Ed.), Religion and Identity in South Asia and Beyond: Essays in Honor of Patrick Olivelle (pp. 347-368). Anthem Press.

---. (2014). Writing Resistance: The Rhetorical Imagination of Hindi Dalit Literature. Columbia University Press.

Burgos-Debray, E. (Ed.). (1984). I, Rigoberta Menchú: An Indian Woman in Guatemala (A. Wright, Trans.). Verso.

Dingwaney, A., \& Maier, C. (1995). Translation as a Method for Cross-Cultural Teaching. In A. Dingwaney \& C. Maier (Eds.), Between Languages and Cultures: Translation and Cross-Cultural Texts (pp. 303319). University of Pittsburgh Press.

Henderson, S. (2001). Latin American Testimonio: Uncovering the Subaltern's Gender, Race, and Class. Ex Post Facto: The History Journal, X, 83-94. https://history.sfsu.edu/sites/default/files/images/2001_Sandra\%20Henderson.pdf

Kamble, B. (2008). The Prisons We Broke (M. Pandit, Trans.). Orient Longman. (Original work published 1986)

Kumar, R. S. (2016). The politics of Dalit literature. In J. K. Abraham \& J. Misrahi-Barak (Eds.), Dalit Literatures in India (pp. 39-57). Routledge India.

León, K. de. (1986). Andar Andando. CEM-Pehuén.

Limbale, S. (2004). Towards an Aesthetic of Dalit Literature: History, Controversies, and Considerations (A. Mukherjee, Trans.). Orient Longman. (Original work published 1996)

Pai, N. (2016). Language and translation in Dalit literature. In J. K. Abraham \& J. Misrahi-Barak (Eds.), Dalit Literatures in India (pp. 76-92). Routledge India. 
Pandian, M. S. S. (2003). On a Dalit Woman's Testimonio. In A. Rao (Ed.), Gender and Caste: Issues in Contemporary Indian Feminism (pp. 129-135). Kali for Women.

Pawar, U. (2008). The Weave of My Life (M. Pandit, Trans.). Stree. (Original work published 2003)

Plummer, K. (1995). Telling Sexual Stories: Power, change and social worlds. Routledge.

Pratibha (2021). Self and Community in Autobiographical Narratives by Dalit Women in the English Translation [Unpublished doctoral dissertation]. Jamia Millia Islamia.

Rancière, J. (2004). The Politics of Literature. SubStance, 33(1), 10-24. https://doi.org/10.2307/3685460 Rao, A. (Ed.). (2003). Gender \& Caste (Issues in Contemporary Indian Feminism). Zed Books.

Rege, S. (2013). Writing Caste/Writing Gender: Narrating Dalit Women's Testimonies. Zubaan.

Shankar, S. (2012). Flesh and Fish Blood: Postcolonialism, Translation, and the Vernacular. University of California Press.

Thomas, S. S. (2016). The politics of Dalit literature. In J. K. Abraham \& J. Misrahi-Barak (Eds.), Dalit Literatures in India (pp. 248-259). Routledge India.

Vergara, J. I. (2018). The voice of the voiceless: critical analysis of the production and interpretation of testimonies in social sciences a Latin American perspective. Journal of Historical Archaeology \& Anthropological Sciences, 3(2), 266-274. https://medcraveonline.com/JHAAS/the-voice-of-thevoiceless-critical-analysis-of-the-production-and-interpretation-of-testimonies-in-social-sciencesa-latin-american-perspective.html

Viramma, Racine, J., \& Racine JL. (1997). Viramma: Life of an Untouchable (W. Hobson, Trans.). Verso.

Winter, F. (2009). Giving Voice to the Voiceless? Second Thoughts on Testimony in Transitional Justice. $A$ Contracorriente - A Journal on Social History and Literature in Latin America, 6(3), 90-107. http://www.tara.tcd.ie/bitstream/handle/2262/33946/Winter.pdf?sequence=1

Pratibha has been an Assistant Professor of English Literature at the School of Humanities and Social Sciences, Sharda University since October 2015. She has been a Research Scholar at the Department of English, Jamia Millia Islamia, New Delhi from 2013 to 2021. She submitted her Ph.D. dissertation titled Self and Community in Autobiographical Narratives by Dalit Women in the English Translation, in January, 2021 and was awarded M.Phil. degree in 2016 for the dissertation titled A Critical Study of Caste and Gender Dynamics in the Poetry of Meena Kandasamy. Her research focuses on Dalit Literature. Some of her published papers can be accessed from her Academia Profile at https://sharda.academia.edu/PratibhaBiswas. She is also a published poet. Her poetry collection Taboo and Other Poems is available as an e-book on the Amazon Kindle platform, accessible at https://www.amazon.in/Taboo-other-Poems-Pratibhaebook/dp/B085RFBHRR. She can be contacted at: pratibhabiswas85@gmail.com. 